\title{
Decoding symbiotic endogeneity: the stochastic input-output analysis of university-business-government alliances
}

Haruo H. Horaguchi

\author{
Correspondence: \\ horaguch@hosei.ac.jp \\ Faculty of Business Administration, \\ Hosei University, 2-17-1, Fujimi, \\ Chiyodaku, Tokyo 102-8160, Japan
}

\begin{abstract}
The theoretical population ecology constructs of commensalism, parasitism, and amensalism are applied in an analysis of the Knowledge Cluster Initiative $(\mathrm{KCl})$, a unique social experiment establishing university-business-government alliances for knowledge-intensive innovative clusters in Japan. An analysis based on multiple negative binomial regressions to confirm the interdependence of the triple helix variables revealed that new startup venture firms served as an input factor for filing new patents and developing new products. Although the ultimate goal of the $\mathrm{KCl}$ was to promote new startups from the university, the startups had a commensal effect on patents and new product development. The Japanese cluster creation policy encouraged academic participation and created a mutual effect of launching new university startups. The resulting increase in the number of university researchers promoted the establishment of new startups. These startups had commensal relationships with patent applications and new product development. Although the creation of new venture startups was the ultimate goal of the cluster promotion policy, the results of this study indicate that it was the universities that benefited from the new startups that commensally contributed to increasing quantities of alliance outputs such as patents and new products.
\end{abstract}

\section{Resumen}

Conceptos de ecología como el comensalismo, parasitismo y amensalismo se aplican en este análisis de la Iniciativa de Aglomeración del Conocimiento (IAC)-un experimento social único en el Japón que establece alianzas universidad-empresagobierno para crear aglomeraciones (clusters) de innovadores intensivos. Un análisis basado en múltiples regresiones binomiales para confirmar la interdependencia de las variables de triple hélice reveló que las firmas nacientes (start-ups) aceleran la producción de nuevas patentes y nuevos productos. La política japonesa de creación de clusters del conocimiento estimuló la participación académica y creó un efecto que reforzó la creación de nuevas start-ups académicas. El aumento resultante en el número de investigadores universitarios promovió también el establecimiento de nuevas startups. Estas startups tienen relaciones comensales con aplicaciones de patentes y desarrollo de nuevos productos. A pesar de que la creación de nuevas empresas de riesgo fue el objetivo final de la política de promoción de clusters, los resultados de este estudio indican que fueron las universidades las que se beneficiaron de las nuevas startups que contribuyeron a aumentar cantidades de productos de alianza como patentes y nuevos productos. 


\section{Résumé}

Les constructions théoriques de l'écologie de la population comme le commensalisme, le parasitisme et l'amensalisme sont appliquées dans une analyse de la Knowledge Cluster Initiative ( $\mathrm{KCl}$, initiative de clusters de connaissances), une expérience sociale unique qui établit des alliances université-industrie-pouvoirs publics pour des clusters de connaissances innovants au Japon. Une analyse basée sur de multiples régressions binomiales négatives en vue de confirmer l'interdépendance des variables de la Triple Hélice a révélé que les nouvelles start-ups d'entreprises capital-risque ont servi de facteurs d'entrée pour la production de nouveaux brevets ou le développement de nouveaux produits. Bien que le but final de la $\mathrm{KCl}$ ait été de promouvoir de nouvelles start-ups à partir des universités, les start-ups ont eu des effets commerciaux sur le développement de nouveaux brevets et produits. La politique japonaise de création de clusters a encouragé la participation des universitaires et créé un effet mutuel de création de nouvelles start-ups universitaires. L'augmentation du nombre de chercheurs universitaires qui en a résulté a favorisé la création de nouvelles start-ups. Ces start-ups ont eu des relations proches du commensalisme quant aux demandes de brevets et au développement de nouveaux produits. Bien que la création de nouvelles start-ups ait été l'objectif ultime de la politique de promotion des clusters, les résultats de cette étude indiquent que ce sont les universités ayant bénéficié des nouvelles start-ups qui ont contribué à accroître le nombre d'alliances, de brevets et de nouveaux produits.

\section{Аннотация}

Относящиеся к теоретическим положениям популяционной экологии комменсализм, паразитизм и аменсализм используются в анализе Программы Научных Кластеров (Knowledge Cluster Initiative - KCl), уникального социального эксперимента, направленного на формирование альянсов между университетами, промышленностью и правительством для последующего создания высокотехнологичных кластеров в Японии. Анализ, основанный на многочисленных отрицательных биномных регрессиях подтверждает взаимозависимость переменных тройной спирали, указывая на то, что новые венчурные фирмы- стартапы выступают в качестве входного фактора для разработки новых патентов и создания новых продуктов. Несмотря на то, что конечной целью KCl являлось продвижение новых стартапов, создаваемых в университетах, они оказывали симбиотический эффект на создание патентов и новых продуктов. Японская политика создания кластеров стимулирует участие научных организаций и оказывает взаимовлияние на запуск новых университетских стартапов. Опосредованно наблюдается рост количества университетских исследователей, создавших новые стартапы. Такие стартапы имеют симбиотические связи с подачей заявок на патент и разработку новых продуктов. Несмотря на то, что создание новых венчурных стартапов является конечной целью стратегии продвижения кластеров, результаты настоящего исследования указывают на то, что университеты получают вследствие создания новых стартапов, которые симбиотически влияют на рост числа результатов формирования альянсов, таких как патенты и новые продукты. 
摘 要

共生、寄生和偏害主义的群生态结构理论被用于分析知识集群计划 $(\mathrm{KCl})$ - — 一 个在日本为知识密集型创新集群建立大学 - 商业 - 政府联盟的一个独特的社会 实验。基于多重负二项回归的分析,我们确认三螺旋变量的相互依赖性,揭示了高 技术新创公司成为提交新专利和开发新产品的投入因素。虽然 KCI的最终目标是 从大学出发促进初创企业,但新创公司在专利和新产品开发方面有共生作用。日 本的集群创建政策鼓励学术界参与,并与开发新的大学初创企业产生相互影 响。由此带来参与的大学研究人员数目的增加,促进了新创公司的建立。这些初 创公司与专利申请和新产品开发有共生关系。尽管创办新创公司是集群发展政 策的最终目标,但我们的研究结果表明:在这些创业公司不断增加联盟的产 出一一如专利和新产品数量一一的同时,大学也受益于这些公司。

\section{Resumo}

As construções teóricas da ecologia de populações como comensalismo, parasitismo e amensalismo são aplicadas em uma análise do Knowledge Cluster Initiative (KCl), um experimento social único que estabelece alianças universidade-empresa-governo em clusters inovadores intensivos em conhecimento no Japão. Uma análise baseada em múltiplas regressões binomiais negativas para confirmar a interdependência das variáveis da Hélice Tríplice revelou que as novas empresas startup serviram como um fator de entrada para a solicitação de novos pedidos de patentes e desenvolvimento de novos produtos. Embora o objetivo final do $\mathrm{KCl}$ fosse promover novas startups a partir da universidade, as startups tiveram um efeito similar ao comensalismo sobre patentes e desenvolvimento de novos produtos. A política japonesa de criação de clusters incentivou a participação acadêmica e criou um efeito mútuo no lançamento de novas startups universitárias. O aumento resultante no número de pesquisadores universitários promoveu o estabelecimento de novas startups. Essas startups tinham relações similares ao comensalismo com pedidos de patentes e desenvolvimento de novos produtos. Embora a criação de novas startups tenha sido o objetivo final da política de promoção de clusters, os resultados deste estudo indicam que foram as universidades que se beneficiaram das novas startups que contribuíram para aumentar as quantidades de alianças, assim como de patentes e novos produtos.

\section{Multilingual abstract}

Please see Additional file 1 for translation of the abstract into Arabic.

\section{Introduction}

A metaphor has been used to describe university-business-government (UBG) relations in the social sciences: the triple helix (Etzkowitz and Leydesdorff 1995, 2000; Benner and Sandström 2000; de Castro et al. 2000; Etzkowitz 2002; Etzkowitz et al. 2005). In these relations, entrepreneurship is promoted under the circumstances of a regional innovation policy in each nation. The triple helix metaphor has been developed to offer an analytical perspective on UBG alliances (Leydesdorff et al. 2006; Leydesdorff and Fritsch 2006; Park and Leydesdorff 2010; Kim et al. 2012) and uses the Shannon-Weaver information entropy model (Shannon 1948) to measure variable overlap. Although the Shannon-Weaver information entropy model can measure the degree to which variables overlaps, it does not reveal the internal structure of UBG alliances. Despite a serious effort to reveal this 
structure through a case study (Petersen et al. 2016), the players within UBG alliances are still naively assumed to cooperate with one another.

The present paper fills this gap. The objective of this paper is to provide a new theoretical foundation to evaluate innovation promotion policy. A 5-year project of UBG alliances in Japan was observed to obtain data from 18 regional clusters. In this article, the internal structure of the triple helix is unveiled by observing the data generated from the alliances. The alliance engaged in collective efforts to create knowledge-based output. For this analysis, the population ecology concepts of symbiotic relationships are applied, producing the discovery that research-driven alliances have evolved a selforganizing structure of influential paths.

Because of the nature of UBG alliances, with cooperation serving as their base, new constructs to describe cooperative strategies must be theoretically established. It is widely acknowledged that corporate strategy theory includes both the competitive and cooperative strategy theories. Thus, the theories of corporate strategy rest on the dichotomy of competition versus cooperation (Porter 1980, 1985; Axelrod and Hamilton 1981; Axelrod 1997; McGrath 2013). Even when the concept of coopetition was proposed, it was essentially defined in terms of win-win or win-lose elements (Brandenburger and Nalebuff 1997, p. 39). This dichotomy is based on the perception that market transactions are pervaded by competitive forces. Transcending this dichotomy is particularly important when firms, universities, research institutes, and government institutions cooperate in UBG alliances (Porter 1998; Lee et al. 2000; Martin and Sunley 2003) because the evolving complex structure of these alliances produces a mixture of unilateral and bilateral influences among participants.

Cooperative strategy theory requires specific constructs to describe how the intermediary forces interconnect within a triple helix. The win-win relationship is a cliché used to describe the goal of cooperation; however, a cooperative strategy does not ensure cooperation to achieve a mutually beneficial relationship among participants. Mutual benefit is the aim when the cooperative strategy is employed in the business field but is not always attained in reality. Some participants may free-ride on their partners, while others may reduce the benefits of the alliance.

Observations of endogenous clusters (Porter 1990; Saxenian 1994; Kenney 2000) rarely provide measurable data to capture a cluster's internal structure because a cluster is typically established over a longer period than that studied by researchers, i.e., the endogenous historical path of a cluster is rarely preserved for the purposes of social sciences (Dosi 1988; George et al. 2002; Markman et al. 2005). Some of the policies designed to encourage innovation creation helped provide data for UBG alliances in Japan (Kodama 2008; Nishimura and Okamuro 2011). As will be explained in the "Research methods" section of this paper, the data in this paper are based on a cluster creation policy in Japan. In essence, a social experiment provided the data for the present paper. Only by observing social experiments can we obtain original data regarding the clusterrelated triple helix.

This paper addresses the following research questions: What types of symbiotic relationships are empirically observed in the triple helix? What types of inputs contribute to achieving the policy goal of creating new startups from universities? Why do some symbiotic relationships in the business ecosystem take nonreciprocal forms when promoting research and business in UBG alliances? These issues are addressed by applying 
the theoretical constructs of population ecology to provide a new foundation for analyzing strategic alliances in business ecosystems.

The second section of this paper develops theoretical constructs and the hypothesis of cooperative strategic management. The extant literature has applied population ecology to incorporate the collective perspective into inter-organizational strategic behavior. This body of literature is extended in this section to explore five distinct patterns of symbiosis for knowledge management. The third section identifies specific UBG alliances in Japan and presents an empirical analysis that identifies the internal structure of the innovation clusters. The fourth section summarizes the findings of the study, and the final section discusses their limitations, including how to expand the theory. It also discusses policy implications and suggestions for future research.

\section{Theoretical development and hypotheses}

\section{Symbiotic patterns in business ecosystems}

In comparison to historical economic thought, which has been deeply influenced by physics, terminologies such as "business ecosystem" and "symbiotic patterns of business alliances" invoke distinctively different attributes to explain the birth of firms and industries. To explain the birth of firms or startup ventures, biology and population ecology are theoretically applied to describe a system as a business ecosystem. An analytical framework for inter-organizational relations was proposed by Astley and Fombrun (1983) and Astley (1984). They proposed an approach called the collective strategy that incorporated the population ecology concept of symbiotic relationships. They applied the adjective "commensalistic" in their research, believing that the concept of symbiotic relationships could be applied to corporate strategy. In ecology, commensalism (Vandermeer and Goldberg 2003) is a situation in which one organism benefits from another without either being harmed, for example, the relationship between crocodiles and Egyptian plovers. To date, the concept of commensalism in collective strategy has been applied in the literature of management strategy (Bresser and Harl 1986; Bresser 1988; Dollinger 1990; Haak 2004). Rigorous empirical studies of this concept, however, have yet to be presented.

Applying population ecology concepts reveals five patterns of coexistence in addition to commensalism. Table 1 summarizes the symbiotic patterns that are potentially exhibited by two different organizations, with "+" indicating a partner who exerts a beneficial influence, "-" indicating a partner whose influence is harmful, and " 0 " indicating that the partner has a neutral influence (Horaguchi 2014). When both parties benefit

Table 1 Five symbiotic patterns for two players

\begin{tabular}{llll}
\hline & Player B & & \\
\hline Player A &,++ &,+ 0 &,+- \\
& Mutualism & Commensalism & Parasitism \\
& $0,+$ & 0,0 & $0,-$ \\
& Commensalism & Neutralism & Amensalism \\
&,-+ &,- 0 &,-- \\
& Parasitism & Amensalism & Competition
\end{tabular}

Note: signs indicate payoffs for the players. The left-hand sign indicates the payoff for player $A$, and the right-hand sign indicates the payoff for player $B$, with " + " representing a positive or beneficial payoff, " 0 " representing a neutral effect, and "-" representing a negative or harmful effect. Source: Horaguchi (2014), with reference to Vandermeer and Goldberg (2003) 
from one another, the result is mutualism $(+,+)$ because the two companies cooperate and create a win-win relationship. When both parties harm one another, the result is competition $(-,-)$ in the terminology of population ecology. In this situation, the two companies compete with one another. The theory of strategic management in economics describes this type of rivalry as cutthroat competition (Scherer 1980), in which both parties are dragged into negative positions; another example is the prisoner's dilemma. The traditional theory of competition uses these two boxes in the two corners in Table 1.

Even when two parties collaborate, one of the parties may be unable to benefit from the other, and the latter therefore receives one-sided benefits; this situation is called commensalism $(0,+)$. Reversing the relationship, if one party is not harmed by the other party and the former benefits from the latter, the result is again commensalism $(+, 0)$. Commensalism, $(0,+)$ and $(+, 0)$, is the case where only one party benefits from the other (Hannan and Freeman 1989, p. 97); this is known as a free-rider problem in economics. It must be noted, however, that commensalism also includes the behavioral characteristic of giving a benefit to an identified party. The identified party may be targeted as a result of altruism or in a strategic choice to give a benefit for some future return. The donor in commensalism is offering a benefit to a target recipient; it could be called a free donor who is happy to let the other party be a free-rider.

When one party benefits the other party but is harmed by that party in return, the result is parasitism $(+,-)$. Under a cooperative agreement, one party may obstruct the joint effort while another party provides benefits, which is again interpreted as parasitism $(-,+)$. Third, when one party achieves no benefit and harms its partner, the result is amensalism $(0,-)$. Similarly, a party might not benefit while also being harmed by the other, again termed amensalism $(-, 0)$. Why did these specific patterns of interdependence emerge? A typical example of amensalism is what social psychologists term "social loafing" (Levi 2014), which refers to a situation in which a group member shirks an order from a superior. This situation provides an example of amensalism $(0,-)$ because one party incurs a loss while the other gains nothing. Including neutralism $(0,0)$, these types of relationships between two players, which are presented in Table 1, can also be applied to participants in UBG alliances.

Cooperative strategies can be analyzed by employing these concepts-commensalism, amensalism, and parasitism-in addition to the concepts of competition and mutualism. The extension of theoretical constructs in cooperative strategy theory to include the concepts of commensalism and amensalism broadens the scope of possible empirical investigations, which can involve unilateral courses of influence from one party to another. In contrast to the nuances associated with the term "cooperation," cooperative strategies can include unilateral influence. The application of the five symbiosis patterns has not been previously tested to analyze clustering in UBG alliances; thus, the following hypotheses will be examined:

Hypothesis 1a. UBG alliances exhibit the features of commensalism $[(0,+)$ or $(+, 0)]$ among participating players.

Hypothesis $1 b$. UBG alliances exhibit the features of parasitism $[(+,-)$ or $(-,+)]$ among participating players.

Hypothesis 1 c. UBG alliances exhibit the features of amensalism $[(0,-)$ or $(-, 0)]$ among participating players. 
The sustainability of UBG alliances

Self-organization in knowledge collaboration does not always produce win-win relationships among collaborators. Self-organization occurs for two reasons, the first of which is the existence of tacit knowledge (Polanyi 1962, 1966). It is difficult to a priori exclude individuals who are unable to contribute to knowledge creation through collaboration (Hayek 1945). The existing theory of coopetition (Brandenburger and Nalebuff 1997) assumes that cooperation creates a win-win relationship between two firms. Mutualism $(+,+)$ corresponds to this type of relationship. Collective knowledge management is explicitly required in this context (Horaguchi 2014). The second reason for self-organization is the existence of externalities. Following Marshall (1890), the concept of an externality explains the existence of specific industry agglomerations found in certain local areas (Feldman 1994; Horaguchi 2008a). The existence of externalities can be considered the source of commensalism in knowledge creation. Marshall (1890) notes that "organization aids knowledge" (book IV, chapter 1: 115) when describing the local knowledge shared in industries.

This bilateral relationship extends to multilateral relationships in the alliance. If the alliance is sustained by multiple types of symbiotic collaboration, the beneficial relationships can compensate for the damaging relationships. If an equal number of mutualistic and competitive relationships exist in an alliance, the total benefit for participants is zero. In such cases, the alliance is unstable. One can thus infer that the number of commensal relationships must exceed the number of amensalistic relationships for an alliance to be stable. Thus, the following hypotheses are proposed:

Hypothesis $2 a$. The total number of cooperative relationships characterized by commensalism and mutualism exceeds the number of conflicting amensalistic and competitive relationships in UBG alliances.

Hypothesis $2 b$. The number of commensalistic relationships exceeds that of amensalistic relationships in UBG alliances.

Hypothesis 2c. The number of mutualistic relationships exceeds that of competitive relationships in UBG alliances.

One must note that even if either hypothesis $2 \mathrm{~b}$ or $2 \mathrm{c}$ is rejected, then hypothesis $2 \mathrm{a}$ could be supported or vice versa. It is interesting to further infer that parasitism tends to be latent because its beneficial and disrupting effects cancel each other out in an alliance. Opportunism in an organization (Williamson 1985) is a typical example of parasitism, in which one actor has an antagonistic effect on a partner. This situation could occur in merger and acquisition situations in which the merging firm mismanages the merged firm.

\section{Knowledge specificity in alliances}

The inclusion of the ecological concepts of commensalism and amensalism extends the theoretical scope of the field of strategic cooperative management. In contrast to the two parties in a bilateral relationship, two parties in a cooperative game with multiple players can interact with unbalanced payoffs. The payoffs of these two parties can be offset by the other players' payoffs. The concept of knowledge specificity addresses this issue of decoding endogenous reciprocity in the triple helix. 
Knowledge specificity is defined as the degree to which one party possesses unique knowledge compared to another party. In this situation, the former is more likely to become a source of commensalism $(0,+)$ and the latter is more likely to become a beneficiary. The high levels of knowledge specificity for the former party mean that it tends to contribute to the other party. In contrast, if two parties with overlapping knowledge specificity are involved in a project, the influential partner in the knowledge domain absorbs the performance of the other. Here, the influential partner influences the former in an amensalistic relationship $(0,-)$, whereas the latter party is hampered by the overlapping knowledge specificity from the former.

The dissemination of knowledge provides an explanation for this theoretical conjecture. Commensalism $(0,+$ or,+ 0$)$ describes an identified relationship in which one party transmits knowledge to the other, and the giver might not necessarily lose anything. If specific knowledge is held by a single party, the knowledge flows from that party to other individuals. Unlike a positive externality, commensalism can be controlled by the owner of the knowledge, who can ultimately refuse to provide benefits to the other participants. When a startup venture profits from the knowledge created by university researchers in the alliance, the former benefits from the academic performance via commensalism. Conversely, the researchers in universities may benefit from the startup venture, in which case, they are enjoying commensalism. Based on the above considerations and assuming that the role of government organizations is neutral, the following hypotheses are proposed:

Hypothesis $3 a$. University researchers and their output, such as academic papers, patents, and prototypes, have positive effects on the creation of new startup ventures from UBG alliances.

Hypothesis $3 b$. The creation of new startup ventures through UBG alliances has positive effects on alliance-driven output, such as patents, prototypes, and new products.

If these two hypotheses coexist, the creation of new startup ventures and the increase in academic output from a cluster creation policy will have a mutually positive effect.

\section{Research methods}

\section{Research overview and data}

The data for this current analysis were retrieved from the Knowledge Cluster Initiative (KCI) in Japan. ${ }^{1}$ This initiative was implemented by the Japanese Ministry of Education, Culture, Sports, Science, and Technology (MEXT), which made the assessment data available to researchers to examine the performance of these alliances. The initiative began in 2002 and included 12 designated areas. Three areas were added in 2003 when the policy was officially implemented, and another three were included in 2004. These three groups of areas completed their first 5-year programs in 2007, 2008, and 2009, respectively.

From 2004 to 2009, the author of this paper conducted field research in all of the 18 designated areas to interview coordinators, university professors and researchers, managers of new startup ventures, and researchers at participating companies under the KCI (Horaguchi 2008b). Equipment purchases were audited at the universities and 
startup ventures to examine how they used the equipment. In 2007, a qualitative questionnaire survey of the area coordinators was conducted by the author to obtain qualitative data for this research.

The MEXT committee's final assessment provided the data for the analysis (Appendix Table 9). MEXT organized an evaluation committee to assess the effectiveness of the $\mathrm{KCI}$ for each area, and the author of this paper served as a committee member from 2009 to 2010. The data for the final assessment were compiled in 2009 and 2010 based on the final report for the 18 areas, which was prepared in March 2010. MEXT employed a think tank to validate the data of the 18 areas for the final assessment. MEXT employed a detailed assessment system to evaluate the midterm performance of the designated areas, and the final assessments were completed in 2010 at the end of the 5-year plan. Both the interim and final assessment reports are available upon request from MEXT. The variables of focus for this quantitative empirical study are based on the qualitative research process of the evaluation committee for the KCI.

The KCI served as a massive social experiment that enabled an assessment of the performance of UBG alliances. The KCI can be considered a social experiment because the time horizon and monetary grant level are controlled among the available data from the designated area. Participants from local universities, companies, and governmental institutions were required to form a consortium in each region to receive grants to promote industry-oriented research. The designated clusters received 500 million yen (4.67 million US dollars in 2004 terms) per year over a 5-year period; in total, 2.5 billion yen (23.4 million US dollars) was granted to each region over this period. Overall, across the 18 designated areas, the project received nine billion yen (84.11 million US dollars) per year, which amounts to a total of 45 billion yen (420 million US dollars) to promote UBG alliances (Figure 3 in Appendix).

Each consortium was expected to serve as a research and development hub by providing a network for business collaboration. Local governmental institutions employed project coordinators and provided research funds to participating university researchers and companies.

\section{Dependent variables, independent variables, and control variables}

The study variables were selected from the datasets in the MEXT final assessment report. In each region, the KCI required a local governmental organization to be responsible for alliance formation among universities, firms, and public research institutions. This was called the central organization. The 18 central organizations were obliged to gather information on the performance of the alliance, which was then reported to the MEXT assessment committee. The performance measurement criteria were discussed in the assessment committee, the meetings of which were attended by the author of this paper.

Each of the central organizations gathered performance data every year to allocate the research funds among the researchers in the KCI alliance. The interim report and the final report of MEXT were published for assessment purposes. It was important to gather performance data for the final report because the KCI participants anticipated that a second round of the 5-year KCI scheme would follow. As noted above, the initiative began in 2002 as a 5-year plan, and additional designated areas were added in 2003 and in 2004. By 2004, the KCI included 18 areas. Depending on the beginning of the 
starting year, the first-round KCI ended in March 2007, March 2008, or March 2009 after the 5 -year project period. For some areas, the second-round KCI scheme had been launched in 2007.

In 2010, the final report of the first round was compiled. In this section, we use the data from the 2010 final report of the first round. Even when clusters such as UBG alliances are examined and comprehensive datasets are obtainable, difficulties in the statistical analysis remain because the alliance's output also serves as its input. For example, the patents granted to one group in a UBG alliance are regarded as an output factor; however, several alliance participants can use those patents as inputs for their R and D products. When the physical characteristics of a prototype are presented in an academic publication, the academics might in turn produce additional patent applications and subsequently publish papers about the product's performance. Consequently, clustering has specific characteristics that are similar to those of boosting circuits; this is referred to as an endogeneity problem in econometrics (Greene 2012). This paper transcends the endogeneity problem by applying multiple negative binomial regression analyses, as explained in the following section.

The definitions of the variables are as follows.

Papers: the number of academic papers published by researchers in the KCI. This variable represents an output factor (Czarnitzki et al. 2009) from the UBG alliances and is also regarded as an input factor for subsequent rounds of patent applications, new product development, startups, and budgetary support from local governments (Bekkers and Bodas Freitas 2008).

Patents: the number of patent applications submitted by participants in the KCI. This variable represents both a cluster output factor (Jaffe 1989) and an input factor for prototypes, products (Toole and Czarnitzki 2009, 2010), and papers (Geuna and Nesta 2006; Meyer 2006; Azoulay et al. 2009).

Trials: the number of prototypes (Jensen and Thursby 2001) sent to trial for new product development projects by the university and businesses in the KCI. This variable captures not only an input factor for new product development but also an output performance measure from the research alliances.

News: the number of news items published in newspapers or appearing in television newscasts during the activities of the KCI. This information was gathered by the coordinators in the central organizations or was reported to them by the participating researchers or companies. This variable is included as an output factor of the KCI. Simultaneously, news items might have benefited the activities of new startups or new business development because these items disseminated information on their activities; thus, the news variable also serves as an input factor (Sine et al. 2007).

Awards: the number of business and academic awards received by the members of the $\mathrm{KCI}$. This variable shows KCI output and might in turn serve as an input factor to promote new business and laboratory activities because awards can help in recruiting top talent (Toole and Czarnitzki 2009, 2010).

Products: the number of products made and sold as a result of the KCI. This variable is an output factor that might also serve as an input factor for new businesses and startups (Rothaermel and Deeds 2004). 
Startups: the number of new startup ventures based on the universities' technological support and the participants' involvement and occasional investment in the KCI. This variable quantifies the cluster output (Landry et al. 2006; Toole and Czarnitzki 2009, 2010). The number of new startups might also serve as an input factor because new startups could have offered equipment and talent for laboratory experiments, which could then have led to publishing academic papers and filing patents. New startups may also have attracted attention from journalists and thus led to newspaper articles that focused on the launched UBG alliances. Coordinators: the number of coordinators employed in each $\mathrm{KCI}$ central organization. This variable represents government initiatives. It is considered an input that influences performance (Di Gregorio and Shane 2003; Bekkers and Bodas Freitas 2008) in both academia and business. The coordinators are the individuals in the central organizations who managed the research funds and allocated them to the researchers who participated in the KCI. The number of coordinators might have increased when the technology license office was expanded because of the heavier management burden. In those cases, the number of coordinators is regarded as an output factor from the $\mathrm{KCI}$ activities.

Firm researchers (FRs): the number of firm researchers involved in KCI research projects. This variable is used as an input factor that reflects the effort to organize researchers to join projects from business-oriented research laboratories (Bercovitz and Feldman 2007). On the one hand, this variable contributed to the production of papers, trials, news, and startups. On the other hand, it is an output factor for the KCI project in the sense that the project introduced firm researchers to attractive research opportunities. The variables, such as papers, patents, trials, and products, attracted firm researchers because they are tools to establish reputations in academic projects.

University researchers (URs): the number of university researchers and technical college researchers who were involved in the KCI research projects. This variable is considered an input variable that reflects efforts to organize researchers from local universities and technical colleges. This variable is also an output factor of the KCI project showing that the project as an input induced academic researchers to engage in attractive research opportunities. The attractiveness of the KCI projects can be demonstrated by variables such as papers, patents, news, and awards.

Table 2 presents the descriptive statistics for the study variables, and Table 3 presents a correlation matrix for the ten variables. Among the 45 correlations listed in Table 3, six pairs have correlation coefficients greater than 0.6. Thus, estimation methods such as ordinary least squares cannot be applied due to multicollinearity. At the initial stage of analysis, Poisson regression was applied to identify symbiotic patterns; however, there was concern about over-dispersion of the Poisson regression among the output variables chosen above (Long and Freese 2014). A stochastic estimation method, negative binomial regression, is thus employed using the maximum likelihood estimation procedure (Cameron and Trivedi 1986; Hausman et al. 1984). The following equation formally expresses the specification of overdispersion which is applied to the negative binomial regression (Verbeek 2012, pp. 233-234):

$$
\mathrm{V}\{\mathrm{yi} \mid \mathbf{x i}\}=\left(1+\delta^{2}\right) \exp \left(\mathbf{x i}^{\prime} \boldsymbol{\beta}\right)>\exp \left(\mathbf{x i}^{\prime} \boldsymbol{\beta}\right)
$$


Table 2 Variables analyzed

\begin{tabular}{llllll}
\hline Variable & Obs. & Mean & Std. dev. & Min. & Max. \\
\hline Papers & 18 & 403.5 & 215.7267 & 103 & 948 \\
Patents & 18 & 138.5 & 73.85777 & 48 & 258 \\
Trials & 18 & 50.77778 & 49.76244 & 0 & 167 \\
Products & 18 & 10.77778 & 10.93594 & 0 & 34 \\
Startups & 18 & 3.722222 & 3.177227 & 0 & 11 \\
News & 18 & 310.4444 & 193.7895 & 80 & 901 \\
Awards & 18 & 27.16667 & 21.45378 & 2 & 79 \\
Coordinators & 18 & 7.222222 & 7.304757 & 2 & 28 \\
FRs & 18 & 63.27778 & 34.4568 & 20 & 119 \\
URs & 18 & 67.27778 & 38.24811 & 13 & 138 \\
\hline
\end{tabular}

where $\exp \left(\mathbf{x i}^{\prime} \boldsymbol{\beta}\right)$ is equal to the Poisson regression model. yi represents the expected value of the dependent variable, given $\mathbf{x i}$. xi captures the vector for the independent variables, and $\left(1+\delta^{2}\right)$ is the term for dispersion. The betas, represented as a vector form of $\beta \mathrm{i}$, are parameter estimates. In the negative binomial model, the disturbance is assumed to have a standard gamma distribution, and it is incorporated into the exponential function to have a variance function $\mathrm{V}$ having $\left(1+\delta^{2}\right)$ (Cameron and Trivedi 1986). I used the "nbreg" command (Long and Freese 2014, pp. 507-509) in STATA ver.10 (StataCorp LP, Texas, USA). The three analytical steps of the estimation procedure using negative binomial regressions are explained below.

\section{First analysis step: multiple negative binomial regressions}

As the first step in the analysis, negative binomial regressions are performed for each dependent variable. Each regression uses the remaining variables as the independent variables. For example, when startups is picked up as the dependent variable, the remaining nine variables-coordinators, papers, patents, trials, products, news, awards, FRs, and URs-serve as independent variables. The results of this regression analysis are presented in Table 4. In the case where startups is the dependent variable, only one independent variable, URs, produces a positive and significant effect at the $5 \%$ level of significance.

Table 3 Correlation matrix

\begin{tabular}{|c|c|c|c|c|c|c|c|c|c|c|}
\hline & Papers & Patents & Trials & Products & Startups & News & Awards & Coordinators & FRs & URs \\
\hline Papers & 1 & & & & & & & & & \\
\hline Patents & 0.4490 & 1 & & & & & & & & \\
\hline Trials & 0.3551 & 0.2103 & 1 & & & & & & & \\
\hline Products & 0.4600 & 0.6001 & 0.5569 & 1 & & & & & & \\
\hline Startups & 0.3584 & 0.6581 & 0.4624 & 0.6939 & 1 & & & & & \\
\hline News & 0.2260 & 0.5285 & 0.0495 & 0.1786 & 0.5344 & 1 & & & & \\
\hline Awards & 0.7384 & 0.4755 & 0.2483 & 0.5372 & 0.3330 & 0.1067 & 1.0000 & & & \\
\hline Coordinators & 0.1631 & -0.1483 & 0.3121 & 0.0787 & -0.1264 & -0.1081 & -0.2187 & 1 & & \\
\hline FRs & 0.2587 & 0.2991 & 0.1617 & 0.0970 & 0.5348 & 0.5802 & 0.0439 & 0.0315 & 1 & \\
\hline URs & 0.5107 & 0.4314 & 0.1981 & 0.3409 & 0.6566 & 0.6874 & 0.4132 & 0.0023 & 0.4852 & 1 \\
\hline
\end{tabular}


Table 4 Negative binomial regression with startups as the dependent variable

\begin{tabular}{lllllll}
\hline & Estimate & Std. err. & $z$ & $P>|z|$ & \multicolumn{2}{c}{$95 \%$ confidence interval } \\
\hline Papers & -0.0005075 & 0.001124 & -0.45 & 0.652 & -0.0027105 & 0.0016955 \\
Patents & 0.0028805 & 0.0029715 & 0.97 & 0.332 & -0.0029436 & 0.0087046 \\
Trials & 0.0030686 & 0.003382 & 0.91 & 0.364 & -0.0035599 & 0.0096972 \\
Products & 0.025599 & 0.0168096 & 1.52 & 0.128 & -0.0073472 & 0.0585452 \\
News & -0.0010361 & 0.0012797 & -0.81 & 0.418 & -0.0035442 & 0.0014721 \\
Awards & -0.0096299 & 0.0124393 & -0.77 & 0.439 & -0.0340105 & 0.0147506 \\
Coordinators & -0.0228675 & 0.0233967 & -0.98 & 0.328 & -0.0687243 & 0.0229892 \\
FRs & 0.0066573 & 0.0058232 & 1.14 & 0.253 & -0.004756 & 0.0180706 \\
URs & 0.014075 & 0.0062625 & 2.25 & $0.025^{* *}$ & 0.0018007 & 0.0263493 \\
Constant & -0.2079478 & 0.4772253 & -0.44 & 0.663 & -1.143292 & 0.7273965 \\
\hline
\end{tabular}

Number of obs. $=18, \mathrm{LR} \mathrm{chi}^{2}(9)=25.14$, Prob $>\mathrm{chi}^{2}=0.0028$, log likelihood $=-30.5917$, pseudo $R^{2}=0.2913$

**Significance at the $5 \%$ level

When the startups variable is defined as the dependent variable a priori in the negative binomial regression analysis, URs is the only statistically significant independent variable. This type of approach is similar to that used by Toole and Czarnitzki (2009, 2010), who employed academic entrepreneurship as the dependent variable a priori. They arbitrarily selected independent variables such as the numbers of awards given to researchers, journal publications, and patent applications. Because their model assumed linear relationships, they did not examine the effects in the other direction, such as the effect of academic entrepreneurship on the number of journal publications.

Classifying certain variables as dependent and others as independent a priori raises the issue of endogeneity. One method to rectify endogeneity is to apply a two-stage least squares (2SLS) estimation for instrumental variables (Shaver 1998; Greene 2012). Due to the nature of UBG clusters, the aforementioned variables are expected to exhibit deep endogeneity in their symbiotic relationships because they mutually influence one another.

Consider the case in which each of the instrumental variables in the 2SLS may exhibit further interactions with the others, which may well be the case for UBG alliances. As a logical step to investigate the stochastic interdependence and to identify commensalism and amensalism, the negative binomial regression must be iterated $n$ times to yield a set of estimations for $n$ variables. This step determines the existence of endogeneity among the $n$ variables.

This research does not claim that endogeneity is avoided through this procedure, as is often claimed in 2SLS analyses. Instead, symbiotic endogeneity is identified by the iteration step. As such, the objective of this paper is to determine variables that potentially exhibit endogeneity with one another. Theoretically, it is inferred that all of the variables in the dataset may be interdependent due to endogeneity. However, it is not empirically known whether any of the variables have mutual symbiosis. This possibility must be examined by iterating the negative binomial regression analyses to account for all possible combinations. Although Table 3 presents a correlation matrix of ten variables, it indicates merely a descriptive analytical level of interdependence. Endogeneity must exist as a characteristic of clustering because each of the ten variables might be a dependent variable with respect to the nine remaining variables in the dataset. Endogeneity is not avoided but is empirically identified by the iteration; when it is identified, we call it symbiotic endogeneity. Thus, the negative binomial regression analyses are performed ten times, once for each variable. 
The results of the negative binomial regression analyses are presented in Table 5. All of the equations correspond to high likelihood ratios, indicating that the estimated equations are statistically significant. The significance levels are indicated by asterisks. A single asterisk indicates $p$ values of less than 10\%, two asterisks indicate less than 5\%, and three asterisks indicate less than $1 \%$.

\section{Second analysis step: identifying symbiotic patterns}

In the second step of the data analysis, the independent variables that exert statistically significant positive effects and those that produce statistically significant negative effects are identified. As discussed above, these variables are candidates for symbiotic endogeneity among variables. After identifying the variables that produce positive and negative effects, the patterns of symbiosis among the variables are revealed. If two paired variables exert mutually positive effects in two sets of negative binomial regressions, the pair is classified as mutualistic $(+,+)$. Similarly, commensalistic $(+, 0)$, parasitic $(+,-)$, amensalistic $(0,-)$, and competitive $(-,-)$ pairs are identified. Adding the three patterns for the commensalistic $(0,+)$, parasitic $(-,+)$, and amensalistic $(-, 0)$ pairs results in the eight types of relationships presented in Table 1.

The information presented in Table 5 is now reorganized to present the significant relationships. The variables that produce significant positive effects and the variables that produce significant negative effects are presented in Table 6. Table 6 highlights the relationships among the variables, presenting the significant effects initially shown in Table 5. Table 6 indicates the following. First, the startups variable is not negatively influenced by any other variable. Second, the variables in the URs-patents, FRs-products, and coordinators-awards pairs exert a negative influence on each other. Table 6 identifies the possible endogeneity among the ten variables obtained in the UBG alliances. It is important to note here again that endogeneity does not prevail in all of the relationships among the variables. Symbiotic endogeneity has been empirically identified by iterating the negative binomial regressions.

The significant positive and negative effects presented in Table 6 are combined to classify pairs into the symbiotic categories of mutualism $(+,+)$; commensalism, $(+, 0)$ or $(0,+)$; parasitism, $(+,-)$ or $(-,+)$; amensalism, $(0,-)$ or $(-, 0)$; and competition $(-,-)$. For example, the commensalism category includes both $(+, 0)$ and $(0,+)$. The two tables are combined by assigning a value of one to a positive relationship between two variables and a value of zero otherwise. Assigning a value of -10 to a negative relationship and a value of zero otherwise for Table 6 results in a new matrix with three potential values in each cell: zero, one, or -10 . Commensalism $(+, 0)$, parasitism $(+,-)$, and amensalism $(0,-)$ are calculated by transposing the above matrix and adding it to the original matrix to obtain the relationships along the diagonal. Cells in the resulting matrix exhibit possible values of zero, one, two, $-9,-10$, and -20 . Cells with a value of one indicate commensalism $(+, 0)$ or $(0,+)$; cells with a value of two indicate mutualism $(+,+)$; cells with a value of -9 indicate parasitism $(+,-)$ or $(-,+)$; cells with a value of -10 indicate amensalism, $(0,-)$ or $(-, 0)$; and cells with a value of -20 indicate competition $(-,-)$. Table 7 presents the results of this reclassification. 
Table 5 Negative binomial regression results

\begin{tabular}{|c|c|c|c|c|c|c|c|c|c|c|}
\hline & Papers & Patents & Trials & Products & Startups & News & Awards & Coordinators & FRs & URs \\
\hline & Estimate & Estimate & Estimate & Estimate & Estimate & Estimate & Estimate & Estimate & Estimate & Estimate \\
\hline Papers & & 0.0003878 & 0.0019982 & -0.0011471 & -0.0005075 & -0.000822 & $0.0019913^{* *}$ & $0.0020987^{* *}$ & 0.0007509 & 0.000372 \\
\hline Patents & 0.0020213 & & -0.0058693 & 0.0007542 & 0.0028805 & $0.0032017^{* *}$ & 0.0002722 & 0.0052762 & -0.002326 & $-0.0035417^{*}$ \\
\hline Trials & -0.0003662 & -0.0022459 & & 0.0052455 & 0.0030686 & 0.0027656 & -0.000123 & $0.0053159^{* *}$ & -0.0009857 & -0.0024319 \\
\hline Products & -0.0065725 & 0.0007825 & 0.0450249 & & 0.025599 & 0.0086098 & $0.0372662^{*}$ & $0.0660849^{* * *}$ & $-0.0328985^{* *}$ & -0.0184543 \\
\hline Startups & 0.014761 & $0.1243858^{*}$ & 0.2232773 & $0.3564944^{* * *}$ & & -0.0853777 & -0.0484681 & $-0.392315^{* * *}$ & $0.1952751^{* *}$ & $0.1839424^{* * *}$ \\
\hline News & -0.0004498 & $0.002076^{* * *}$ & -0.0020413 & 0.0023371 & -0.0010361 & & -0.0001816 & $-0.0037774^{* * *}$ & 0.0012457 & $0.0014496^{* *}$ \\
\hline Awards & $0.0180523^{* * *}$ & 0.0108764 & 0.0087642 & $0.0391269 * * *$ & -0.0096299 & -0.0042698 & & $-0.0479349^{* * *}$ & 0.0039464 & 0.011365 \\
\hline Coordinators & $0.0328804^{* *}$ & 0.0164426 & 0.0289329 & $0.0800816^{* * *}$ & -0.0228675 & -0.0109672 & $-0.0352251^{*}$ & & 0.0196168 & $0.0285669^{*}$ \\
\hline FRs & 0.004684 & -0.0056978 & -0.0025063 & $-0.0283662^{* * *}$ & 0.0066573 & 0.0046658 & 0.0020593 & $0.0144034^{* * *}$ & & -0.0029751 \\
\hline URs & 0.0006778 & $-0.0093233^{* *}$ & -0.0183635 & -0.0094974 & $0.014075^{* *}$ & $0.0114156^{* * *}$ & 0.0003994 & $0.0206261^{* * *}$ & -0.005406 & \\
\hline Constants & $4.721542^{* * *}$ & $4.252516^{* * *}$ & $3.905068^{* * *}$ & 0.5139409 & -0.2079478 & $4.738657^{* * *}$ & $2.201655^{* * *}$ & $0.7372642^{*}$ & $3.490512^{* * *}$ & $3.284915^{* * *}$ \\
\hline LR $\operatorname{chi}^{2}(9)$ & 24.65 & 19.66 & 4.22 & 24.10 & 25.14 & 21.45 & 19.19 & 26.73 & 13.87 & 20.79 \\
\hline Prob $>c h i^{2}$ & 0.0034 & 0.0201 & 0.8960 & 0.0041 & 0.0028 & 0.0108 & 0.0237 & 0.0015 & 0.1270 & 0.0136 \\
\hline Log likelihood & -107.66353 & -91.102238 & -81.331139 & -48.021726 & -30.591776 & -105.09601 & -66.877113 & -39.790913 & -80.553414 & -79.42172 \\
\hline Pseudo $R^{2}$ & 0.8606 & 0.0974 & 0.0253 & 0.2006 & 0.2913 & 0.0926 & 0.1254 & 0.2515 & 0.0793 & 0.1157 \\
\hline
\end{tabular}


Table 6 Significant effects identified by the Poisson regressions

\begin{tabular}{|c|c|c|c|c|c|c|c|c|c|c|}
\hline & \multicolumn{10}{|c|}{ Dependent variables } \\
\hline & Papers & Patents & Trials & Products & Startups & News & Awards & Coordinators & FRs & URs \\
\hline \multicolumn{11}{|c|}{ Independent Variables } \\
\hline Papers & -- & & & & & & ${ }^{* *}+$ & ${ }^{* *}+$ & & \\
\hline Patents & & --- & & & & ${ }^{* *}+$ & & & & $*_{-}$ \\
\hline Trials & & & --- & & & & & $*_{+}^{* *}$ & & \\
\hline Products & & & & --- & & & $*_{+}$ & $*^{* * *}+$ & $*^{* *}$ & \\
\hline Startups & & $*_{+}$ & & ${ }^{* * *}+$ & --- & & & $* * *$ & ${ }^{* *}+$ & ${ }^{* * *}+$ \\
\hline News & & $* * *+$ & & & & --- & & $* *{ }_{-}$ & & $*^{*}+$ \\
\hline Awards & $* * *+$ & & & ${ }^{* * *}+$ & & & --- & $* * *$ & & \\
\hline Coordinators & $*_{+}^{* *}$ & & & ${ }^{* * *}+$ & & & $*_{-}$ & --- & & $*_{+}$ \\
\hline FRs & & & & $* *{ }_{-}$ & & & & ${ }^{* * *}+$ & --- & \\
\hline URs & & $*_{-}^{*}$ & & & $*_{+}^{* *}$ & ${ }^{* * *}+$ & & $* * *+$ & & --- \\
\hline
\end{tabular}

*Significance at the $10 \%$ level; ${ }^{* *}$ significance at the $5 \%$ level; ${ }^{* * *}$ significance at the $1 \%$ level. The triple hyphens "-" indicate the diagonal cell for each variable

\section{Third analysis step: visualization and testing hypotheses}

The third step of the analysis is to visualize the internal structure of the triple helix variables. This step allows us to check the hypotheses and interpret the possible relationships among the variables. Table 7 presents the features of mutualism, commensalism, amensalism, and competition; parasitism is not observed. Thus, as suggested in hypotheses 1a and 1c, commensalism, and amensalism are observed. Due to a lack of parasitism, hypothesis $1 \mathrm{~b}$ is rejected.

A symmetrical mutualistic $(+,+)$ relationship is observed for eight pairs of variables (16 variables) among 45 such pairs (90 variables): papers-awards, papers-coordinators, patents-news, products-awards, products-coordinators, coordinators-URs, startupsURs, and news-URs. The variables obtained through the KCI exhibit mutually beneficial relationships for approximately one-sixth of the potential variable pairs.

These relationships are shown by single-line double-headed arrows in Fig. 1. Eight of the ten variables hence exhibit at least one mutually beneficial relationship with another triple helix variable; trials and FRs are the only variables that do not exhibit

Table 7 Mutual symbiotic interdependencies among variables

\begin{tabular}{|c|c|c|c|c|c|c|c|c|c|c|}
\hline & Papers & Patents & Trials & Products & Startups & News & Awards & Coordinators & FRs & URs \\
\hline Papers & -- & - & - & - & - & - & $\mathrm{Mu}$ & $\mathrm{Mu}$ & - & - \\
\hline Patents & - & -- & - & - & - & $\mathrm{Mu}$ & - & - & - & $C p$ \\
\hline Trials & - & - & -- & - & - & - & - & $\mathrm{Cm}$ & - & - \\
\hline Products & - & - & - & -- & - & - & $\mathrm{Mu}$ & $\mathrm{Mu}$ & $\mathrm{Cp}$ & - \\
\hline Startups & - & $\mathrm{Cm}$ & - & $\mathrm{Cm}$ & -- & - & - & $\mathrm{Am}$ & $\mathrm{Cm}$ & $\mathrm{Mu}$ \\
\hline News & - & $\mathrm{Mu}$ & - & - & - & -- & - & $\mathrm{Am}$ & - & $\mathrm{Mu}$ \\
\hline Awards & $\mathrm{Mu}$ & - & - & $\mathrm{Mu}$ & - & - & -- & $\mathrm{Cp}$ & - & - \\
\hline Coordinators & $\mathrm{Mu}$ & - & - & $\mathrm{Mu}$ & - & - & Cp & -- & - & $\mathrm{Mu}$ \\
\hline FRs & - & - & - & $C p$ & - & - & - & $\mathrm{Cm}$ & -- & - \\
\hline URs & - & $C p$ & - & - & Mu & $\mathrm{Mu}$ & - & $\mathrm{Mu}$ & - & -- \\
\hline
\end{tabular}

Note: Mu represents mutualism $(+,+), \mathrm{Cm}$ represents commensalism $(+, 0)$, Pa represents parasitism $(+,-)$, Am represents amensalism $(-, 0)$, and $\mathrm{Cp}$ represents competition $(-,-)$. The single hyphen "-" means no significance and the double hyphens "-" show the diagonal cell for each variable 


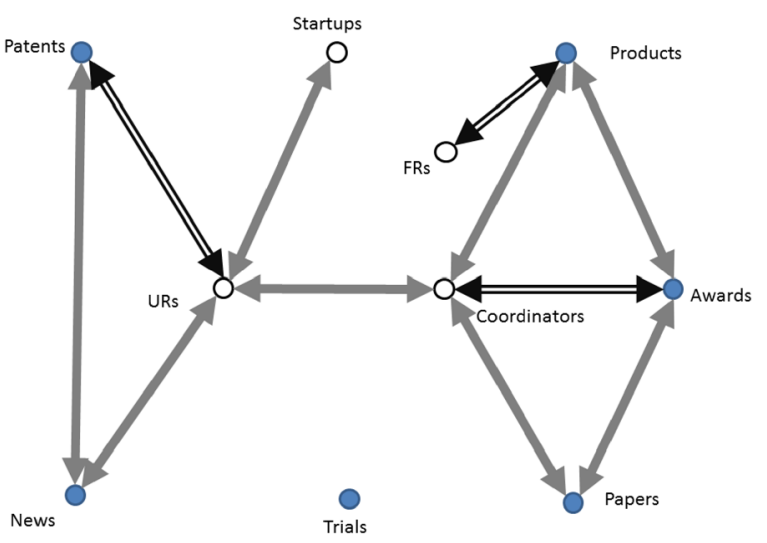

Fig. 1 Mutualism and competition among cluster variables. Note: single-line two-sided arrows indicate mutualism and double-line two-sided arrows indicate competition

mutualism with any of the other variables. The startups variable has a mutualistic relationship only with URs. The UBG alliance was not structured by mutualism, or a strictly win-win relationship, among the variable pairs.

In Fig. 1, the following three variable pairs exhibit competition (-, -), i.e., six variables exert mutually negative effects: patents-URs, products-FRs, and coordinatorsawards. This result is interpreted as follows: these pairs are mutually exclusive because they involve competition with a set target. For example, the competitive relationship between patents and URs suggests that the number of URs will not increase if they obtain a series of patents through their research. If URs are not capable of filing patents, then other university researchers might be induced to participate in the alliance. The competitive relationship between products and FRs indicates that the development of eye-catching products may not induce firm researchers to engage in the UBG alliances. The competitive relationship between coordinators and awards suggests that even if the number of coordinators is large, they do not necessarily promote award-winning practices in the UBG alliances. It also suggests that, on the contrary, if awards are won by URs or FRs in the UBG alliance, then the number of coordinators is not increased. These competitive relationships suggest that the three actors, URs, FRs, and coordinators, act to minimize their efforts given the performance measurement of patents, products, and awards. In the final section, we will again discuss the reasons why the patents variable has a negative effect on the URs variable.

Of 90 possible combinations, there are five cases of commensalism. Figure 2 indicates how commensal relationships connect six variables. Among them, the startups variable commensally influence three variables: patents, products, and FRs. For instance, the startups-patents commensal relationship indicates that new startups exert a positive effect on patent applications; however, the reverse effect is not supported.

Hypotheses 3a and 3b are tested by checking Fig. 2 and Table 8. Hypothesis 3a is thus rejected due to the result that patents, papers, and trials do not have a statistically significant positive impact on the startups variable. The present study affirms that the number of university startups is not influenced by academic publications, by patent applications from university-business partnerships, or by prototypes made in the partnership laboratories. Hypothesis $3 \mathrm{~b}$ is partially supported because the startups variable as 


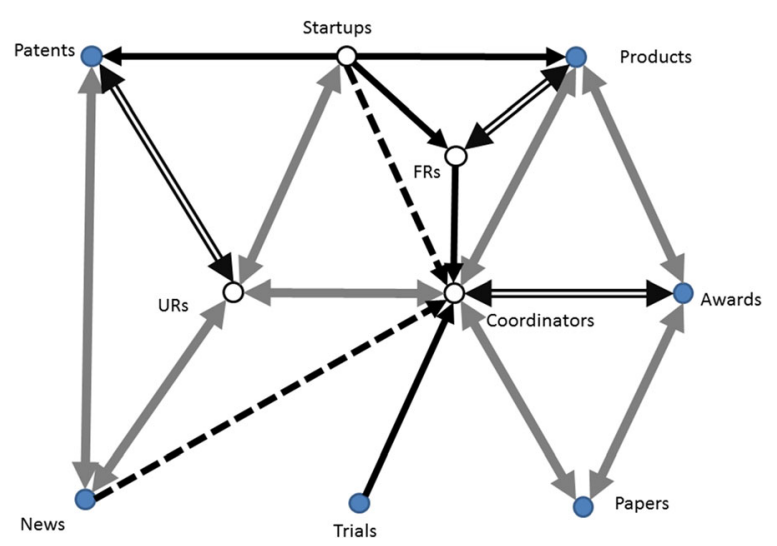

Fig. 2 Commensalism and amensalism among cluster variables. Note: dotted arrows indicate amensalism, single-line one-sided arrows indicate commensalism, single-line two-sided arrows indicate mutualism, and double-line two-sided arrows indicate competition

the independent variable has statistically significant commensal effects on the dependent variables of patents and products but does not influence papers and trials.

The present study thus affirms that the creation of university startups boosts the production of patents and new products. Because of its commensal impacts, the startups variable serves as an input factor in the UBG triple helix. Establishing new venture startups increases the production of patents and new products as hypothesized. It also commensally contributes to the FRs variable in UBG alliances.

As Fig. 2 indicates, two cases of amensalism are observed for the news-coordinators and startups-coordinators variable pairs. The coordinators variable is negatively affected by the startups and news variables; however, there are no effects in the reverse direction. As inferred as the case of amensalism, the number of coordinators might be increased when alliance performance was not satisfactory. On the other hand, if there was a sufficient amount of news coverage and university startups, then additional coordinators would not be employed in the alliance.

The results of the classification presented in Table 7 are summarized in Table 8. Of the 90 possible combinations, 29 exhibit statistically significant interdependencies. There are 16 cases of mutualism, six cases of competition, five cases of commensalism, two cases of amensalism, and no cases of parasitism $(+,-)$. Table 8 indicates that hypotheses $2 \mathrm{~b}$ and $2 \mathrm{c}$ are supported; in particular, in the UBG alliances, the number of commensalistic relationships exceeds the number of amensalistic relationships, and the number of mutualistic relationships exceeds the number of competitive relationships. Hence, hypothesis $2 \mathrm{a}$ is supported because the number of cooperative relationships (i.e., the sum total of mutualism and commensalism) exceeds the number of conflicting relationships (i.e., the sum total of competition and amensalism) in the UBG alliances.

Table 8 Summary of symbiotic interdependencies

\begin{tabular}{lllllll}
\hline Mutualism & Competition & Commensalism & Amensalism & Parasitism & No relation & Total \\
\hline 16 & 6 & 5 & 2 & 0 & 61 & 90 \\
\hline
\end{tabular}




\section{Discussion}

\section{Symbiotic endogeneity in the business ecosystem}

Among the 90 possible combinations, eight variable pairs exhibit mutualistic and three exhibit competitive relationships. If the theoretical constructs are confined to the traditional concepts of competition and cooperation, statistical analysis will identify only relationships that involve symmetrical patterns of variable pairs. Among our possible combinations, however, there are five cases of commensalism and two cases of amensalism. It is notable that the startups variable is involved in only one mutualistic relationship, that with URs (Fig. 1). The dichotomy of competition versus cooperation fails to depict the pathways of influence in the triple helix structure that create new startup ventures.

To ensure the uniqueness of introducing the concepts of commensalism and amensalism, the correlation matrix in Table 3 must be compared with the symbiotic interdependencies in Table 7. The results of the simple correlation matrix differ considerably from the results provided by the multiple negative binomial regressions and the subsequent identification of commensalism and amensalism. For example, although the products and startups variables are strongly correlated (0.6939), the present analysis finds a commensal relationship in which the startups variable exerts a beneficial effect on the products variable, but not one in which the reverse is true. Common types of analyses, such as panel data analyses and structural equation modeling, presuppose dependent and independent variables for which one of a pair of variables has a decisive effect on the other. On the contrary, the data analysis in the present study has the characteristics of exploratory research because it identifies specific broken symmetrical relationships that exhibit commensalism and amensalism.

The startups variable and its links provide theoretical insights into the business ecosystem. Incorporating commensalism into the analysis provides strong evidence for how variables are organically connected. With respect to the policy goal of creating new startups, startup ventures are supposed to be led by entrepreneurs who utilize technology developed by the university researchers participating in the KCI. On the contrary, the startups variable serves as an input factor for the products, FRs, and patents variables. Figure 2 illustrates the effects of the startups variable, which serves as an input factor and also acts as an output variable due to its links with URs. The participating startups increase their output of patents and products due to the commensal effects; however, the reverse effect is not observable. This result is counterintuitive given that the promotion of university-led startups is sometimes emphasized as one of the ultimate goals of the cluster creation policy.

\section{Knowledge specificity and amensalism}

Commensalism occurs because university startups are allowed to retain trade secrets as specific knowledge, whereas scientific practice requires sharing innovative progress through academic publication, which undermines knowledge specificity. This logic is applied to the startups-patents and the startups-products commensal relationships. Another example of knowledge specificity occurs when the patents 
variable has competition with respect to URs (Fig. 2). Given that the knowledge specificity of the patents variable overlaps with that of the URs variable, new patents in the UBG alliances may substitute for the role played by the URs. The patents variable substitutes for specialized knowledge required for URs, who increase the uniqueness of this knowledge. The activity of filing new patents may reduce the level of effort exerted by URs, who would otherwise make an effort to file new patent applications. Figure 2 adds the competitive effect representing the conflict of interest between the FRs and products variables. This conflict implies that firm researchers will lose their novelty in $\mathrm{R}$ and $\mathrm{D}$ productivity via new product development.

In Fig. 2, amensalism is observed between the startups-coordinators pair and the news-coordinators pair. The emergent pattern of amensalism is similar to "social loafing" (Levi 2014), which refers to a situation in which a group member shirks an order from a superior. The relationship between the startups-coordinators and newscoordinators pairs demonstrate the degree to which the coordinators can shirk their duties as long as the university startups are spontaneously established and the news stories are covered by the local media.

\section{Limitations}

It is worth noting the limitations of our research. The present research uses data obtained from the $\mathrm{KCI}$ in Japan. It includes various types of projects such as biochemistry, medical science, semiconductor development, and optronics. The empirical results can be interpreted from the viewpoint of knowledge specificity by further qualitative case studies. Horaguchi (2008b, 2014), for example, depicts a case in the Toyama Biomedical Cluster project among the KCI projects. In the Toyama region (Appendix, Figure 3), an alliance was organized by the University of Toyama, Toyama Industrial Technology Center, Ritchell Corporation, and Sugino Machine Ltd. The alliance resulted in forming a university-launched venture, called SC World, Inc., which conducted integration of a cell screening system and collection of antibodies using cell chips. The use of cell chips made it possible to obtain data from more than 250,000 micro-wells (apertures) per square centimeter. Professors Atsushi Muraguchi and Hiroyuki Kishi at the University of Toyama were the board members of SC World Inc., and they published joint papers in various journals, such as Blood and the Journal of Immunology. This case illustrates an essential part of the present statistical research; the KCI had an impact on rejuvenating the academic performance. More in-depth description through field research would certainly contribute to providing a theoretical foundation for innovation policy.

An additional limitation can be found in the lack of parasitism in the UBG alliances. A wide variety of economic phenomena fall under the category of parasitism, such as joint research and development projects, joint ventures in a foreign country, and consortium loans and recovery of funds. In future studies, new insights regarding the conflicting dimensions of cooperative strategy will be examined using the construct of parasitism. These are the limitations of our paper, and future research will be able to expand our analysis. 


\section{Policy implications}

The policy implication is clear. The Japanese cluster creation policy encouraged URs who were eager to become involved in UBG alliances. There is evidence that an increase in the number of URs involved in UBG collaborations directly promoted the establishment of new startups. The startups associated with the Japanese cluster creation policy accelerated patent application productivity. These startups also had a direct commensal relationship with new products. Although creation of new startup ventures was the ultimate goal of the cluster promotion policy, the results of this study indicate that repercussions occurred. The new startup ventures had a positive effect on productivity with respect to filing collaborative patents, developing products, and increasing new participants from among firm researchers. The number of participants from among university researchers positively influenced the number of new startup ventures (or vice versa). The interdependence between the startups and patents variables provides a typical example of commensalism (Fig. 2).

As indicated in Table 9 of Appendix, 68 startup ventures were established among 1211 university researchers, whereas 2518 patents were filed as a result of the UBG alliances. According to our statistical analysis, the startups provided commensal benefits to the academic participants. The startups variable had a positive effect on products, FRs, patents, and URs variables so that the startups variable could outweigh the negative effects among productsFRs and patents-URs variables shown in Fig. 1. The coefficients in the negative binomial regression results in Table 5 indicate that the startups variable had a larger coefficient of one decimal place whereas other variables showed two to three decimal places for their estimated coefficients. Table 2 shows that the maximum number of the startups variable was 11, whereas that of papers was 948 and that of patents was 258. This difference in magnitude implies that the establishment of startup ventures boosts the output of large number of knowledge-based products. Regarding policy measures for promoting science and technology, the startups variable had important effects on academic variables, such as the papers variable.

Figure 2 indicates that the startups variable created a positive feedback loop that boosted academic performance when the commensalism and mutualism variables are interpreted in terms of their logical consequences. The startups variable increased the production of papers through several positive feedback loops. The startups-products link began a direct feedback loop, which was reinforced by a products-awards-papers path. A longer loop, such as the startups-patents-news-URs-coordinators-papers loop, included the mutualistic relationships. These links suggest that the KCI had a positive impact on rejuvenating the academic performance for the participating universities.

Figure 2 suggests furthermore that the expertise of coordinators bridges academia and business through the startups-FRs-coordinators-papers-awards-products linkage. In the $\mathrm{KCI}$, the coordinators are typically appointed by non-profit central organizations organized by the local governments. As Fig. 2 illustrates, the eight linkages are connected by the coordinators variable. Different types of expertise and technological skills are linked to ultimately generate new startup ventures. These linkages provide an example of how, in the words of Marshall (1890), "organization aids knowledge." The coordinators play an important role by linking the participants in the UBG collaborations. They select and connect participants to maintain the performance of the triple helix. 


\section{Endnote}

${ }^{1}$ A possible direct translation of the Japanese title of the policy, Chiteki Kurasutaa Sousei Jigyou, is "Intellectual Cluster Creating Initiatives." The English title, the Knowledge Cluster Initiative, is officially used by the MEXT.

\section{Appendix}

\section{Knowledge Cluster Initiative data}

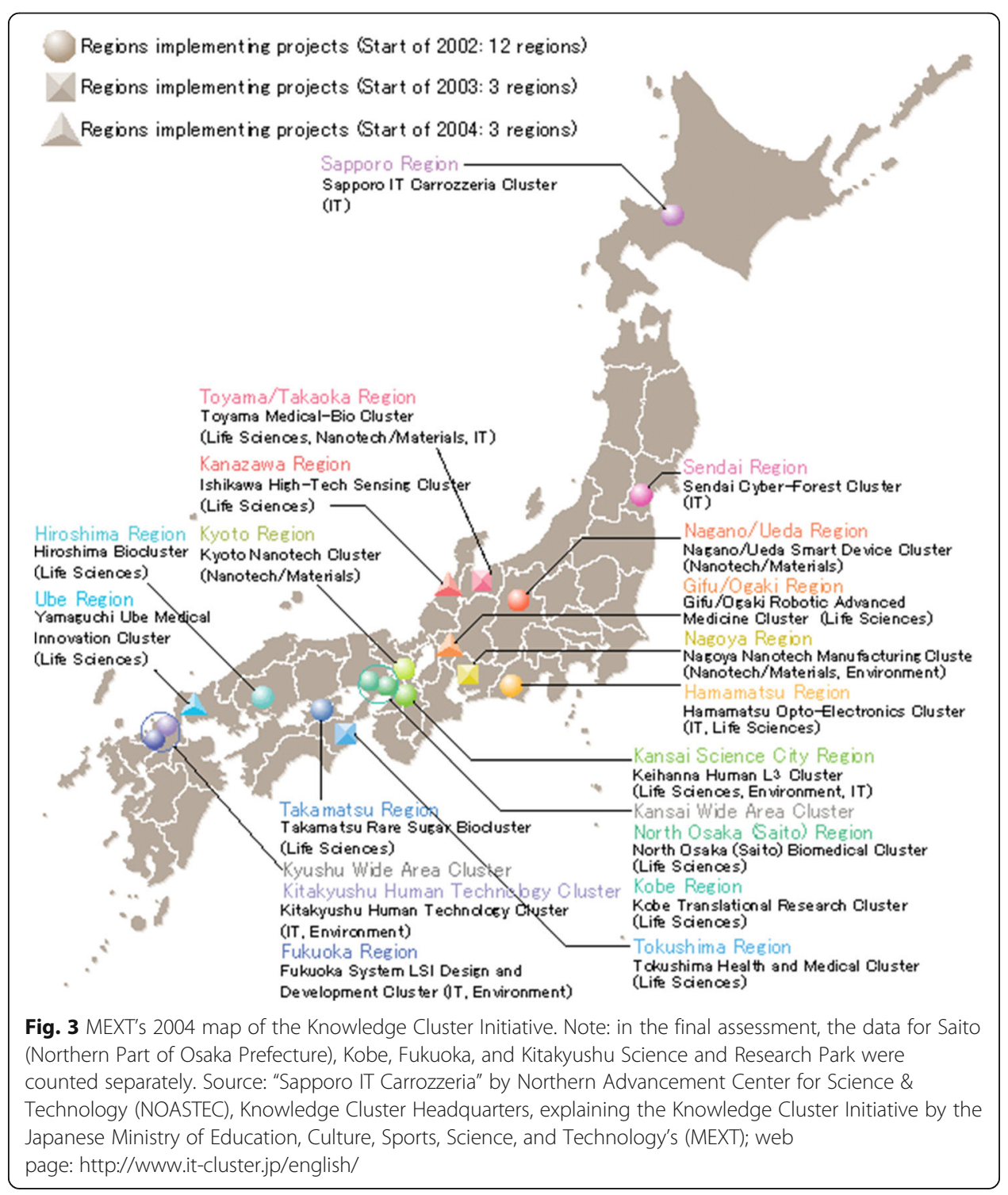


Table 9 MEXT final assessment data

\begin{tabular}{|c|c|c|c|c|c|c|c|c|c|c|c|}
\hline & $\begin{array}{l}\text { Coordinators in } \\
\text { the final year }\end{array}$ & Papers & Patents & Trials & $\begin{array}{l}\text { New } \\
\text { products }\end{array}$ & $\begin{array}{l}\text { New } \\
\text { businesses }\end{array}$ & Startups & News & Awards & $\begin{array}{l}\text { Firm } \\
\text { researchers }\end{array}$ & $\begin{array}{l}\text { University researchers } \\
\text { including Politechnique }\end{array}$ \\
\hline Sapporo & 3 & 175 & 62 & 41 & 9 & 5 & 3 & 259 & 29 & 20 & 20 \\
\hline Sendai & 3 & 255 & 141 & 68 & 19 & 2 & 1 & 159 & 41 & 21 & 20 \\
\hline Nagano, Ueda & 2 & 391 & 233 & 0 & 0 & 0 & 7 & 901 & 22 & 119 & 138 \\
\hline Hamamatsu & 3 & 285 & 254 & 0 & 9 & 11 & 6 & 307 & 9 & 35 & 31 \\
\hline Kansai Science City & 6 & 581 & 240 & 167 & 29 & 0 & 11 & 389 & 29 & 95 & 83 \\
\hline Osaka North (Saito) & 3 & 363 & 53 & 0 & 0 & 0 & 4 & 116 & 17 & 104 & 58 \\
\hline Kobe & 9 & 381 & 83 & 0 & 0 & 0 & 0 & 80 & 10 & 38 & 13 \\
\hline Hiroshima & 12 & 407 & 93 & 0 & 0 & 0 & 0 & 321 & 23 & 98 & 50 \\
\hline Takamatsu & 6 & 103 & 81 & 0 & 0 & 0 & 0 & 219 & 2 & 31 & 46 \\
\hline Fukuoka & 3 & 213 & 48 & 99 & 0 & 0 & 0 & 269 & 11 & 93 & 37 \\
\hline Kitakyushu Science and Research Park & 24 & 487 & 153 & 133 & 15 & 7 & 5 & 353 & 23 & 104 & 77 \\
\hline Toyama, Takaoka & 4 & 192 & 97 & 7 & 5 & 1 & 2 & 340 & 5 & 46 & 73 \\
\hline Aichi, Nagoya & 5 & 608 & 238 & 10 & 19 & 3 & 4 & 159 & 49 & 41 & 42 \\
\hline Kyoto & 5 & 588 & 196 & 42 & 26 & 0 & 7 & 534 & 33 & 100 & 116 \\
\hline Tokushima & 7 & 229 & 71 & 58 & 14 & 3 & 6 & 223 & 15 & 37 & 106 \\
\hline Kanazawa & 4 & 948 & 118 & 90 & 7 & 1 & 2 & 279 & 79 & 40 & 117 \\
\hline Gifu, Ogaki & 3 & 449 & 258 & 55 & 25 & 10 & 8 & 322 & 66 & 82 & 112 \\
\hline Ube & 28 & 499 & 99 & 81 & 14 & 0 & 2 & 246 & 13 & 35 & 72 \\
\hline Total & 130 & 7154 & 2518 & 851 & 191 & 43 & 68 & 5476 & 476 & 1139 & 1211 \\
\hline
\end{tabular}




\section{Additional file}

Additional file 1: Translation of the abstract into Arabic. (PDF $116 \mathrm{~kb}$ )

\section{Acknowledgements}

This work was supported by JSPS KAKENHI Grant Number JP26245048.

\section{Competing interests}

The author declares that he has no competing interests.

Received: 10 August 2016 Accepted: 1 December 2016

Published online: 09 December 2016

\section{References}

Astley WG (1984) Toward an appreciation of collective strategy. Acad Manag Rev 9:526-535

Astley WG, Fombrun CJ (1983) Collective strategy: the social ecology of organizational environments. Acad Manag Rev 8:576-587

Axelrod R (1997) The complexity of cooperation. Princeton University Press, Princeton

Axelrod R, Hamilton WD (1981) The evolution of cooperation. Basic Books, New York

Azoulay P, Ding W, Stuart T (2009) The impact of academic patenting on the rate, quality and direction of (public) research output. J Ind Econ 57:637-676

Bekkers R, Bodas Freitas IM (2008) Analysing knowledge transfer channels between universities and industry: to what degree do sectors also matter? Res Policy 37:1837-1853

Benner M, Sandström U (2000) Institutionalizing the triple helix: research funding and norms in the academic system. Res Policy 29:291-301

Bercovitz JEL, Feldman MP (2007) Fishing upstream: firm innovation strategy and university research alliances. Res Policy 36:930-948

Brandenburger AM, Nalebuff BJ (1997) Co-opetition. Currency Books, New York

Bresser RKF (1988) Matching collective and competitive strategies. Strateg Manag J 9:375-385

Bresser RK, Harl JE (1986) Collective strategy: vice or virtue? Acad Manag Rev 11:408-427

Cameron AC, Trivedi PK (1986) Econometric models based on count data: comparisons and applications of some estimators and tests. J Appl Econom 1:29-54

Czarnitzki D, Glänzel W, Hussinger K (2009) Heterogeneity of patenting activity and its implications for scientific Research. Res Policy 38:26-34

de Castro EA, Rodrigues C, Esteves C, da Rosa Pires A (2000) The triple helix model as a motor for the creative use of telematics. Res Policy 29:193-203

Di Gregorio D, Shane S (2003) Why do some universities generate more start-ups than others? Res Policy 32:209-227

Dollinger MJ (1990) The evolution of collective strategies in fragmented industries. Acad Manag Rev 15:266-285

Dosi G (1988) Sources, procedures, and microeconomic effects of innovation. J Econ Lit 26:1120-1171

Etzkowitz H (2002) Incubation of incubators: innovation as a triple helix of university-industry-government networks. Sci Public Policy 29:115-128

Etzkowitz H, Leydesdorff L (1995) The triple helix — university-industry-government relations: a laboratory for knowledge based economic development. EASST Review 14:14-19

Etzkowitz H, Leydesdorff L (2000) The dynamics of innovation: from national systems and "mode 2" to a triple helix of university-industry-government relations. Res Policy 29:109-123

Etzkowitz H, de Mello JMC, Almeida M (2005) Towards "meta-innovation" in Brazil: the evolution of the incubator and the emergence of a triple helix. Res Policy 34:411-424

Feldman MP (1994) Knowledge complementarity and innovation. Small Bus Econ 6:363-372

George G, Zahra SA, Wood DR Jr (2002) The effects of business-university alliances on innovative output and financial performance: a study of publicly traded biotechnology companies. J Bus Venturing 17:577-609

Geuna A, Nesta LJJ (2006) University patenting and its effects on academic research: the emerging European evidence. Res Policy 35:790-807

Greene WH (2012) Econometric analysis, 7th edn. Pearson Education, Essex

Haak R (2004) Theory and management of collective strategies in international business: the impact of globalization on Japanese-German business collaboration in Asia. Palgrave Macmillan, Basingstoke

Hannan MT, Freeman J (1989) Organizational ecology. Harvard University Press, Cambridge

Hausman JA, Hall BH, Griliches Z (1984) Econometric models for count data with an application to the patents-R\&D relationship. Econometrica 52:909-938

Hayek FA (1945) The use of knowledge in society. Am Econ Rev 35:519-530

Horaguchi HH (2008a) Economics of reciprocal networks: collaboration in knowledge and emergence of industrial clusters. Comput Econ 31:307-339

Horaguchi HH (2008b) Collective knowledge and collective strategy: a function of symbiotic knowledge for businessuniversity alliances, Working paper series no. 57, Research Institute for Innovation Management, Hosei University

Horaguchi HH (2014) Collective knowledge management: foundations of international business in the age of intellectual capitalism. Edward Elgar Publishing Limited, Cheltenham

Jaffe AB (1989) Characterizing the "technological position" of firms, with application to quantifying technological opportunity and research spillovers. Res Policy 18:87-97

Jensen R, Thursby M (2001) Proofs and prototypes for sale: the licensing of university inventions. Am Econ Rev 91:240-259 
Kenney M (ed) (2000) Understanding Silicon Valley: the anatomy of an entrepreneurial region. Stanford University Press, Stanford

Kim Y, Kim W, Yang T (2012) The effect of the triple helix system and habitat on regional entrepreneurship: empirical evidence from the U.S. Res Policy 41:154-166

Kodama T (2008) The role of intermediation and absorptive capacity in facilitating university-industry linkages —an empirical study of TAMA in Japan. Res Policy 37:1224-1240

Landry R, Amara N, Rherrad I (2006) Why are some university researchers more likely to create spin-offs than others? Evidence from Canadian universities. Res Policy 35:1599-1615

Lee C, Miller WF, Hancock MG, Rowen HS (2000) The Silicon Valley edge: a habitat for innovation and entrepreneurship. Stanford University Press, Stanford

Levi D (2014) Group dynamics for teams, 4th edn. Sage Publishing House, Los Angeles

Leydesdorff L, Fritsch M (2006) Measuring the knowledge base of regional innovation systems in Germany in terms of a triple helix dynamics. Res Policy 35:1538-1553

Leydesdorff L, Dolfsma W, Van der Panne G (2006) Measuring the knowledge base of an economy in terms of triplehelix relations among 'technology, organization, and territory'. Res Policy 35:181-199

Long JS, Freese J (2014) Regression models for categorical dependent variables using Stata, 3rd edn. Stata Press Publication, College Station

Markman GD, Phan PH, Balkin DB, Gianiodis PT (2005) Entrepreneurship and university-based technology transfer. J Bus Venturing 20:241-263

Marshall A (1890) Principles of economics, 8th edn. Macmillan, London

Martin R, Sunley P (2003) Deconstructing clusters: chaotic concept or policy panacea? J Econ Geogr 3:5-23

McGrath RG (2013) The end of competitive advantage: how to keep your strategy moving as fast as your business. Harvard Business Review Press, Boston

Meyer M (2006) Are patenting scientists the better scholars? An exploratory comparison of inventor-authors with their non-inventing peers in nano-science and technology. Res Policy 35:1646-1662

Nishimura J, Okamuro H (2011) Subsidy and networking: the effects of direct and indirect support programs of the cluster policy. Res Policy 40:714-727

Park HW, Leydesdorff $L$ (2010) Longitudinal trends in networks of university-industry-government relations in South Korea: the role of programmatic incentives. Res Policy 39:640-649

Petersen AM, Rotolo D, Leydesdorff L (2016) A triple helix model of medical innovation: supply, demand, and technological capabilities in terms of medical subject headings. Res Policy 45:666-681

Polanyi M (1962) The republic of science: its political and economic theory. Minerva 1:54-73

Polanyi M (1966) The tacit dimension. Peter Smith, Gloucester

Porter ME (1980) Competitive strategy: techniques for analyzing industries and competitors. Free Press, New York

Porter ME (1985) Competitive advantage: creating and sustaining superior performance. Free Press, New York

Porter M (1990) Competitive advantage of nations. Free Press, New York

Porter ME (1998) On competition. Harvard Business School Press, Boston

Rothaermel FT, Deeds DL (2004) Exploration and exploitation alliances in biotechnology: a system of new product development. Strateg Manag J 25:201-221

Saxenian A (1994) Regional advantage: culture and competition in Silicon Valley and Route 128. Harvard University Press, Cambridge

Scherer FM (1980) Industrial market structure and economic performance. Houghton Mifflin, Boston

Shannon CE (1948) A mathematical theory of communication. Bell Syst Tech J 27(379-423):623-656

Shaver JM (1998) Accounting for endogeneity when assessing strategy performance: does entry mode choice affect FDI survival? Manag Sci 44:571-585

Sine WD, David RJ, Mitsuhashi H (2007) From plan to plant: effects of certification on operational start-up in the emergent independent power sector. Organ Sci 18:578-594

Toole AA, Czarnitzki D (2009) Exploring the relationship between scientist human capital and firm performance: the case of biomedical academic entrepreneurs in the SBIR program. Manag Sci 55:101-114

Toole AA, Czarnitzki D (2010) Commercializing science: is there a university "brain drain" from academic entrepreneurship? Manag Sci 56:1599-1614

Vandermeer JH, Goldberg DE (2003) Population ecology: first principles. Princeton University Press, Princeton

Verbeek M (2012) A guide to modern econometrics, 4th edn. John Wiley \& Sons, West Sussex

Williamson OE (1985) Economic institutions of capitalism. Free Press, New York

\section{Submit your manuscript to a SpringerOpen ${ }^{\circ}$ journal and benefit from:}

- Convenient online submission

- Rigorous peer review

- Immediate publication on acceptance

- Open access: articles freely available online

- High visibility within the field

Retaining the copyright to your article

Submit your next manuscript at $\boldsymbol{\sim}$ springeropen.com 